\title{
PESTALOZZI AND FICHTE - THE POWER OF EDUCATION
}

\author{
Zoran Dimić ${ }^{1}$ \\ University of Niš, Faculty of Philosophy
}

\begin{abstract}
The text explores the relationship between Pestalozzi and Fichte. The author argues that, with the exception of Kant, Pestalozzi had probably the strongest influence on the development of Fichte's philosophy, and especially on his placing education in the focus of his philosophy. The influence of Pestalozzi on Fichte is most visible in Fichte's critique of the existing education and the construction of a completely new conception of educational activity. It is at this point that Fichte directly relies on Pestalozzi's insights into the importance of independence and self-activity in pedagogical practice. At the same time, there are significant differences between the two of them, clearly visible in Fichte's conception of national education. This conception of Fichte must by no means be viewed only from the context of The Addresses to the German Nation but must be viewed as a whole of the development of Fichte's philosophy, and especially in relation to the historical and educational circumstances that prevailed at the time.
\end{abstract}

Keywords: education, independence, self-activity, selfishness, nation.

\section{General connection between Fichte and Pestalozzi}

The close theoretical connection between Fichte (Johann Gottlieb Fichte) and Pestalozzi (Johann Heinrich Pestalozzi), the greatest pedagogue at the beginning of the modern age, becomes clear exactly when we talk about the key characteristic of Fichte's work in philosophy. Namely, apart from renewing the original idea of the educational character of philosophy itself, attested through the understanding of philosophy as teaching, Fichte also restored the philosophical faith in another very important thing. Judging by all his philosophical and life activities, there is no doubt that Fichte in philosophy restored faith in the meaning and power of the spoken word. With it, the awareness of the importance of great speakers and rhetoricians returns to philosophy. ${ }^{2}$

\footnotetext{
${ }^{1}$ zoran.dimic@filfak.ni.ac.rs

${ }^{2}$ The best presentation of this aspect of Fichte's philosophy is given by H. Seidel in his monograph on Fichte. For more details on this, see: Seidel, H. (1997). J.G.Fichte. Hamburg., p. 118.
} 
In the meantime, and after the Greeks and Romans, with the disappearance of faith in the power of oral, direct communication, awareness of the importance of living speech and teaching among philosophers and scientists has almost completely faded. Without problematizing the relationship with ordinary listeners, to whom philosophy is also directed by its nature, philosophers self-satisfyingly developed their thoughts and theories exclusively in the form of written texts and professional lectures designed for an educated philosophical and scientific audience. Philosophy and science thus barely reached ordinary people. The struggle for a new understanding of education and upbringing by humanists and Comenius, and through Rousseau and Pestalozzi, goes hand in hand with the commitment to the realization of the principle of ,school for all“. This kind of school should make education and upbringing available to absolutely everyone, not just rich people. Pestalozzi's persistent and ardent practical activity in this direction deeply inspired Fichte. By opening the topic of Fichte's relationship with „live“ performances in front of the audience, we do not face, however, only his human character, i.e. specific characteristics of him as a person. It would be wrong to understand his tendency to develop philosophy through ,live" communication with the audience, exclusively as one feature of his personality. The story of Fichte as a speaker and rhetorician, ${ }^{3}$ indicates the essence of his understanding of philosophy as such, and the way of philosophizing as a specific activity of philosophers.

In this sense, it would be really interesting to connect Fichte and Socrates and look for similarities and differences in their way of understanding philosophy and philosophizing. Although there are many differences between them (Socrates, e.g. he did not write at all), it seems to us that many more similarities can be found between them. Unfortunately, the idea that it is possible to connect Socrates' and Fichte's understanding of philosophy was found only with one of the researchers of Fichte. ${ }^{4}$

Helmut Seidel makes the best and perhaps most accurate assessment of Fichte's specific understanding of philosophy and, in particular, the differences between Fichte and other philosophers of German idealism: „Fichte was the only one of the great German philosophers who turned a lecture chair into a tribune, sometimes a tribunal. Leibniz corresponded, Kant taught with his characteristic accuracy, Schelling's performances were aristocratic, Hegel wrestled with words in his lectures, in order to express his deep thoughts. Fichte's head and heart were full and they forced him: 'step out of the word!'“ (Seidel, 1997: 118)

Fichte's overall understanding of philosophy as a teaching, and his attitude towards philosophical practice, confirm that he also testifies to the duty of scientists

\footnotetext{
${ }^{3}$ About Fichte as a rhetorician see also: Scholz, H. (1914). Fichte als Erzieher. Kantstudien 19., p. 160161. Scholz says: „With these extraordinary talents and strengths, he won the youth first. A new, neverbefore-seen spirit blazed from his words. Because he spoke powerfully and not as a scientist. Caught in the flames himself, he ignited (or inflamed) the hearts of his young listeners, until they ignited (or inflamed) themselves and until the inner glow of delight shone from their eyes. He took them more seriously than anyone else. They let him take them and they rejoiced. He spoke about the highest ideals. Those ideals thus became real to them; for he was, what he spoke and taught. He saw them bigger than they were, and they grew larger as he watched them. He demanded a fight and got the victory".
}

${ }^{4}$ It is Heinrich Scholz. See in more detail: Scholz, H. (1914). Fichte als Erzieher. Kantstudien 19., p. 160. 
and the idea of serving the general interest by personal example. Thus, the true unity of his personality and philosophy is confirmed in total. His philosophical activity outside the framework of narrow philosophical circles in which he was uncomfortable, as he himself confirmed in The Foundations of the Entire Science of Knowledge, is behind every thought of his, but also vice versa. This is the basic strength and charisma of the vitality of Fichte's philosophical figure, and also the secret of the vitality of its philosophical actuality, even today, many years after his death.

\section{Belief in the power of education}

The following topic introduces us to a more detailed consideration of the relationship between Fichte and Pestalozzi's pedagogical heritage. Namely, somewhere in the mid-phase of Fichte's philosophical development, there was a theoretical shift from the problem of legal and customary coercion to morality to the problem of educating students, and later the problem of national education, as a method of achieving adequate moral behavior. Fichte's definitions of the essence, organization, and purpose of the university directly point us to that. In that sense, both of Fichte's writings on the essence and organization of the university must necessarily be interpreted as preparation for the later development of a concept of a completely new upbringing, i.e. the upbringing of the nation. The work of one of Fichte's great contemporaries, the greatest pedagogue of that time and certainly the most famous German educator, Pestalozzi, will also play a great role in creating that concept. In the period before writing Patriotism and its Opposite and The Addresses to the German Nation, Fichte intensively dealt with Pestalozzi's writings. Pestalozzi's specific method of education will directly influence Fichte in establishing his idea of educating the nation, but at the same time, Fichte will fundamentally differ from Pestalozzi's ideas on some issues.

Since law and coercion to good customs did not guarantee morality, freedom, and independence, Fichte believed that he must achieve these in a completely different way. In order to move his contemporaries to a general liberation from selfishness and egoism and the removal of the external yoke of slavery, i.e. in order to mobilize the living power of the German people, Fichte had to create an educational system like Pestalozzi's, which would establish the principles of national education. Education thus becomes the crucial question of the culture of a nation. With its help, Fichte could neutralize the negative effects of poor upbringing and education, ${ }^{5}$ and prepare the younger generations to understand the teaching of science and its spirit. ${ }^{6}$ Until then, he tried to create conditions for the development of freedom in his philosophy

\footnotetext{
${ }^{5}$ Compare Fichte's citation about this: „This skill should disappear and something else should appear, which ... should develop freedom"., SW, XI, 265.

${ }^{6}$ Fichte describes the current situation as follows, which must be overcome by a new upbringing: „... so it is immediately clear that, where truth is extinguished in the genus and each individual lives only in his own misty world, pure selfishness necessarily becomes the only instinct of human life, while citizenship, morality, and religion must necessarily disintegrate“., SW, XI, 262.
} 
of the state with the help of law and ethics of duty, and now he is looking for a proper educational skill, which can make it possible to achieve a cultural goal by strong action at the will of the individual. A new educational method and a new theory of education should actually save the destiny of The Doctrine of Science, i.e. to activate it in a new way.

At the time of writing The Patriotic Dialogues (1807), Fichte was particularly interested in Pestalozzi's work, whom he also personally met during one of his stays in Zurich. Fichte believed that Pestalozzi possessed a method by which he could properly build the personality of the pupil and which could therefore serve as a basic method by which the whole nation could be shaped on completely different foundations. The origin of Pestalozzi's method, which is complexly elaborated in his rich practice, is in the principle of independence, as the basis of upbringing and education of the subject. Children should develop not positive knowledge, therefore, not an objective attitude, but understanding, and not speech, but speaking. It is ,the basic means for the development of self-consciousness" (Fichte, 1845/1846: 270). Fichte had really expected a lot from the application of Pestalozzi's method. He said: „Pestalozzi's thought is infinitely greater than he himself ... He did not think these thoughts himself, or created them, but the eternal mind in him thought them ... The essence of Pestalozzi's life was love for the poor, abandoned people. His love enabled him to find more than he was looking for, the unique cure for all of humanity. He found the means to educate a whole one generation, which is otherwise capable of understanding intelligent science ... he illuminated the goal of the Doctrine of Science itself" (Fichte, 1845/1846: 267).

Pestalozzi equally based his theory on the personal activity of the spirit of the pupil to whom no positive and objective knowledge is taught and on love. However, love does not have a metaphysical meaning for him, but a concrete meaning of parents' love for their children. In that sense, his pedagogical thoughts on the understanding of social relations arose from his personal benevolence towards the people, and not from some previously abstractly derived theory of education. In addition, and which is equally important for Fichte, Pestalozzi not only found a method by which humanity would be put on its feet and by which it could be "cured", but at the same time the same that method should have an equally beneficial effect on Fichte's Doctrine of Science itself. Fichte indirectly admits here that the very idea and conception of The Doctrine of Science fell into a certain crisis at that time, and of course, it is not difficult to guess what kind of crisis is meant. However, understanding The Doctrine of Science in this way, he indirectly confirms our thesis that it itself, as a teaching, is directly related to its realization, i.e. to its fulfillment through understanding and acceptance by Fichte's contemporaries, and that this is the only way for The Doctrine of Science to gain its meaning.

Fichte further describes Pestalozzi's idea and method of education in a little more detail, clearly emphasizing its specificities and its uniqueness: „Pestalozzi's thought must be understood in the sense, not of the intellectual upbringing of a poor, oppressed people, but of the absolutely necessary elementary upbringing of all future generations and all generations from now on, in order for it to be properly understood and adequately valued“ (Fichte, 1845/1846: 268). 
Thus, Fichte was attracted not only by Pestalozzi's method which set as its ultimate goal the development of independence and freedom of pupils, but also by the fact that his idea of education did not refer only to certain classes and social strata, but also to the broad poor strata of society who must also be affected by upbringing. Only in this way can it really be ,education as national education“. Another reason for choosing Pestalozzi's role model in education is the fact that it was completely permeated and based on practice, and also on the development of specific practical methods in working with children. Pestalozzi directly helped Fichte to, through the method of education for the self-activity and independence of the entire nation, make the problem of education become a problem of national education. In that sense, The Patriotic Dialogues are really a preparation for The Addresses to the German Nation.

\section{Points of divergence}

In both conceptions of education, in Fichte's and Pestalozzi's, the full realization of human nature is conceived as the final purpose of educational activity. This task has to be accomplished through submission to general moral principles and eternal „divine laws“ (Pestalozzi). At this point, however, there are still many differences between Fichte and Pestalozzi.

Since Pestalozzi was firmly convinced that, based on the eternal laws of human nature, his rules of upbringing were generally valid, he thought that he still had to translate them into the language of different classes of society in order to make them understandable. Fichte, under the influence of his earlier conceptions, and especially under the experience of the French Revolution, has a different view on this. According to the concept from The Addresses to the German Nation, Fichte is closer to understanding national education as universal and abolishing educational differences in different classes. Fichte's critique of certain definitions of Pestalozzi's method refers to those of its shortcomings which are conditioned by the general reluctance towards a political-revolutionary solution to the problem (Fichte, 1845/1846: 404). While Pestalozzi does not demand political changes, Fichte considers their transformation to be a condition for a new concept of upbringing.

In order for children to become independent as quickly as possible through performing various occupations, Pestalozzi, according to Fichte, attaches too much importance to reading and writing. Fichte also disagrees with his understanding of language as a means ,of elevating our race from darker understandings to clearer concepts“" (Fichte, 1845/1846: 405). The next disagreement between Pestalozzi and Fichte concerns the environment in which the pupils should live. In order to realize his plan of education, Fichte demands strict isolation of the pupils from their external environment. The meaning of this can be understood only if we keep in mind Fichte's constant critique of his own times: „If we have a spark of love for them (youth) we must remove them from our infected atmosphere and we must create for them a 'clean' place to live“" (Fichte, 1845/1846: 421). This attitude towards the pupils, Pestalozzi considers completely unnatural. In order to start a new upbringing, Fichte 
with this treatment wants to break with the past of the pupil. As mentioned above, Fichte very often saw a good upbringing in a kind of combination of military attitude and a free-spirited, revolutionary way of thinking.

\section{Education and nation}

Although there were many differences in their views, Fichte's understanding of the method by which the revival in the education of the nation should be carried out was partly marked by Pestalozzi's ideas. Most researchers in the reconstruction of Fichte's conception of upbringing do not start at all from the basic idea of his philosophy or especially his conception of philosophizing, or from the difference between his philosophy and Kant's, but mostly one-sidedly rely exclusively on his late work The Addresses to the German Nation. ${ }^{7}$ It is by no means our intention to dispute the importance of that writing in constructing the overall picture of Fichte's conception of upbringing. On the contrary, we consider it extremely important for Fichte's understanding of this topic. We hold, however, that those controversial parts of this writing, which were largely the reason for the critique of Fichte's theory of education, made it impossible for this work to be ,read" more constructively and to be viewed in its entirety.

The Addresses to the German Nation are a work that strongly connected Fichte with the German movement for liberation from the French occupation in 1813. His speeches made him known also as a political writer to the entire German people. In The Addresses, perhaps most powerfully in comparison with his other writings, his determination and eloquence, strong will, and power of persuasion come to the fore.

The key topic of The Addresses is the creation of a new world. With the help of awakening national consciousness and new upbringing, a new man should be formed, who will create a different moral order and a different state. As the understanding of cosmopolitanism with a German patriotic character, Fichte sees the development of humanity and the general defense of national interests through the German case. ${ }^{8}$ Fichte forms his concept of upbringing through a critique of the existing way of upbringing, referring here especially to the ideas of the Enlightenment. Following Pestalozzi's ideas, upbringing should not make any „cosmetic changes“ in a person affecting only its intellect, but ,should penetrate to the root of life itself". According to Fichte, the German people are particularly receptive to such an upbringing, as they possess one particular feature.

Using the idea of a proto-normal people, which is understood as the bearer of the cultural progress of humanity, Fichte claims that the Germans are a people who, above all other people, ,have the right to call themselves a people, in the true sense of a proto-people". German is equated with the primal. Fichte concludes:

${ }^{7}$ See e.g. Seidel, H. (1997). Johann Gottlieb Fichte zur Einführung. Hamburg., p. 126-133, and also, Rohs, P. (1991). J.G.Fichte. Beck. Muenchen., p. 161-165.

${ }^{8}$ Ibid. 266. 
„Only a German truly has a people“. ${ }^{9}$ What distinguishes the Germans from other people is first of all the fact that they, in their history, have always remained in their first settlements, while other tribes have changed their settlements. The essence of this argument, however, is not in space, but in the fact that the peoples who moved elsewhere at the same time accepted another language, from which other differences in historical development arise. Fichte here, of course, primarily has the French in mind. For Fichte, continuity is obviously important for the development of language itself, „since people are more shaped by language than language by people“. Through eventual linguistic assimilation, the loss of the entire identity occurs (Fichte, 1845/1846: 319). Remaining in their original places, the Germans perfected their original language in uninterrupted continuity. In the picture of language, it can also be seen in members of one nation the picture of the condition of education, upbringing, and the power of understanding and insight. Renouncing one's language in order to accept another language also means destroying one's life roots. Fichte here, of course, alludes to the fact that the Gauls renounced their original language in order to accept Latin. Fichte thus very sharply concludes this discussion of language, pointing out that ,a German can therefore understand the abroad more thoroughly than it can understand itself" because he carries within himself the primal. It is therefore ,impossible to compare the Neo-Latin language with German because a comparison between death and life is not possible“" (Fichte, 1845/1846: 329).

Driven by the general German hatred towards the occupier, Fichte also sees the difference between the French and the Germans in the attitude of these peoples towards classical antiquity. According to him, the Germans are more aware of the necessity of ,perfecting the human with the help of classical antiquity" 10 (Fichte, 1845/1846: 341). Fichte pays special attention to German merits during the Reformation, paying special attention to Luther, to whom as a great rhetorician, he cultivates special, almost self-pleasing sympathies (Seidel, 1997: 131). With all these allegations, Fichte simply wants to awaken and make the dormant German consciousness and national dignity active. The political writer in Fichte wants to move his nation to external and internal liberation.

Another great topic of The Addresses to the German Nation is Fichte's teaching on upbringing. The new upbringing should liberate the German people inside and out and ensure a better future for the entire nation. Fichte does not imagine it as something that should only be externally applied to the youth, but on the contrary as something that should ,unmistakably build and determine their inner life“. At the same time, it should defeat the freedom of capricious will and establish a strict necessity and determination. What he has in mind here is not any training that destroys freedom with the help of external coercion, but a new „education of character", which aims to base the pupil on independence and self-activity. The basic views of

\footnotetext{
${ }^{9}$ This idea is derived from The Characteristics of the Present Age. See: SW, VII, p. 130. See also in The Addresses: SW, VII, p. 280.

${ }^{10}$ On the relation to classical languages, by means of the relation to the thing in itself, see Fichte's small treatise, Aphorisms on Education (1804), SW, VIII, p. 353-360.
} 
The Doctrine of Science here should also determine the essence of education. Fichte, however, takes into account the national characteristics of the German character in his upbringing, but above all, he morally establishes it (Fichte, 1845/1846: 283). He says: „Education is the education of man as man“ (Fichte, 1845/1846: 301), and at the same time he is noting that ,the Germans, however, must set an example to all of humanity" (Fichte, 1845/1846: 306).

The initiator of education is "love“, „desire“, „aspiration“. Without it, the education would be ,dead and cold“(Fichte, 1845/1846:300). Here we see the strong influence of Pestalozzi in the best way. The goal is to move the pupil to personal activity, cognition, free self-activity, and not to give him ready-made, positive knowledge. The new upbringing should develop the creative forces of the pupils with the help of personal examples, exactly as Pestalozzi did with his pedagogical practice, and awaken in them joy and love for learning and action. The goal of that education is not to know one existing condition, but to shape a new reality. What is effective action in The Doctrine of Science (German: Tathandlung), that is in The Addresses the demand for self-activity as the basic principle of education.

Therefore, in education for self-activity by means of a ,complete transformation of the human race" Fichte sees a means of salvation for the German nation. Pestalozzi's method is a great inspiration here. Further, Fichte describes the work in educational institutions in more detail. This public school should live not only completely isolated from society, but also completely independent. Pupils must produce everything themselves (food, clothes, tools), in order to build a proper attitude towards physical work and reliance on themselves alone and their activities from the beginning. Fichte says:,$\ldots$ that it is a shame that someone else supports a pupil for life, and not himself alone with his work ... pupils should get to know humanity exclusively in this way, side by side, relying on themselves" (Fichte, 1845/1846: 422).

All must be educated to subordinate the whole by performing their duties. Only in this way are they morally educated in the right way. According to Fichte, only institutional education guarantees education for morality (Fichte, 1845/1846: 417). Fichte proposes a school like this to the state. It should force everyone to a general upbringing. This would also reduce the costs for the army because a general public education prepares a general people's army. This also reduces spending on the economy, the judiciary, and the police. In addition, the state thus resolves its worries about the present and the future. In this context, Fichte also proposes the abolition of the divided German principalities and the formation of a united German state.

Although in the analysis of the differences between the French and the Germans, and the glorification of characters from German history, he falls into a certain mythologization and mystification, Fichte returns to the basic course of his philosophy in solving the problems facing the entire nation. In other words, he seeks a solution to the problems in upbringing and education, therefore, he places a solution in the inner spiritual transformation of the Germans themselves. To that end, he actualizes the mechanism of coercion in The Addresses, which does not mean that he comes into direct contradiction with the last goal of human liberation. Coercion is just a way to annul the bad consequences of the previous upbringing to 
which Fichte directs his criticism. About the previous upbringing, he says this: „Up to now, upbringing has only largely reminded us of good order and morality, but this admonition has become unfruitful for real life ... it is in this acceptance and counting on the free will of the pupils that lies the first misconception of upbringing and clear recognition of its impotence and nothingness" (Fichte, 1845/1846: 280).

Fichte simply wants to say that resolving the dilemmas faced by the German people and humanity as a whole is no longer possible in the old educational paradigm: „One morally positive upbringing, i.e. one which sets itself a goal and expresses it as if the pupils are being educated for virtue - does not exist: on the contrary, such an action would kill the inner moral sense and would educate heartless hypocrites ...?" (Fichte, 1845/1846: 358). Sporadic appearances of morality in society cannot guarantee any internal unity of the community. The problem can be solved only if there is a possibility for a universal moral education. Such upbringing must enable a decisive unity of mind. Understood in this way, the whole of Fichte's dealing with this issue acquired the character of a saving link between law and morality!

Due to the emphasis on the continuity of this text with Fichte's earlier work, the following should also be said. If you look a little more carefully at the text itself, you can see that Fichte's emphasis on building a new approach to education, and as he says, as a whole ,a new order of things“ (Fichte, 1845/1846: 9), lies primarily in criticism of "selfishness as a basic obstacle to education“ (Fichte, 1845/1846: 12-13). It seems to us that this is the main reason why we can say that, in elaborating the topic of education, despite the usual interpretations, through The Addresses to the German Nation Fichte does not actually lose the thread with his earlier understanding. Criticizing selfishness (German: Selbstsucht) actually means nothing else but criticizing people for forgetting what their true nature really is. Criticizing selfishness means encouraging people to turn to their true nature, i.e. community, nation. Selfishness is something that distances man and nation from their true goals, that is, perfection and unity within the individual and the nation as a whole. Moral motives related to life in the community, and the duties that a person has in it, must take the place of selfish and personal ones. Therefore, for Fichte, the nation is a community, a framework, a certain place that provides space for moral action and education of the individual. Given that the current crisis in Germany has led to a general decline in all values and norms that keep the nation in unity, Fichte's nationalist outbursts and reminders of the general and personal values of the German nation can be understood as an attempt to separate his contemporaries from themselves alone and their confinement in their own complacency, and to bring them back to living together with other people.

The general loss of illusions in the power of the revolution, and numerous national and personal disappointments, have contributed to Fichte no longer speaking here in the categories of universal values and the improvement of man as a genus, i.e. the improvement of the oneness of the genus as a whole, but, which seems much closer to the then harsh reality and real life, he advocates changing the disease condition in which the specific human community in which he himself lived is. The progress of people and the progress of the community depend much more on 
concrete practical and political steps, such as education, than on abstract nurtures of universal ethical and aesthetic values, for which, for example, the Renaissance and humanism advocated. ${ }^{11}$ Fichte's outbursts of nationalism should be understood only as an attempt to support the consciousness of the nation, i.e. for people to turn to other people in the community, and to live together in it, and in that way to fight against the natural laziness they carry within themselves, so that by activity, performing duties and serving, they would overcome selfishness and egoism in themselves. Fichte wants the nation to be a strong norm again, according to which people will be educated. Caring for the nation is actually caring for the people, because there is no greater educator than the nation itself, that is, the community in which man lives.

\section{Conclusion}

There is no doubt that after Kant, Pestalozzi, primarily with his pedagogical practice and fundamental ideas about education, had the strongest influence on the internal development of Fichte's philosophy, and especially on his interest in educational problems. Fichte's insistence on the importance of independence and self-activity in the field of education derives its origin directly from the influence that Pestalozzi exerted on him. Also, Pestalozzi's methods in the education of children and youth, and his pedagogical practice, had a great influence on the development of Fichte's new idea of education from The Addresses. At the same time, it is not difficult to conclude that Pestalozzi would not agree with many of Fichte's ideas from The Addresses.

Of course, on the other hand, Fichte's conception of national education has its many difficulties. Can a universal education for morality really make law and the state unnecessary? Fichte sometimes seemed to have too much confidence in the above discussed sinless action of the „new upbringing“. Then there are other practical issues, such as this: who will educate in this imperfect world? Many objections can also be made to Fichte's idea that children and youth should be educated in a closed circle of an isolated school community. Our goal here, of course, was not to deal in detail with all aspects of Fichte's theory of national education, but only to look at those aspects of it that are relevant to Fichte's relationship with Pestalozzi. Like the entire Romantic era, Fichte's theory of national upbringing suffers from a certain dose of naive romantic enthusiasm and too much faith in the power of the idea of a new upbringing. Preoccupied with the idea of education, Fichte for a moment put aside his earlier insights into the importance of the proper functioning of the legal order and the state for the successful functioning of a community. Carried by romantic wings, Fichte believed for a moment that the idea of a new upbringing could by hand, almost in a magical way, take away all the existing legal and political problems of the time and community in which he lived. All the naivety and numerous

\footnotetext{
${ }^{11}$ In that sense, Fichte's observation about why the Germans did not have their own renaissance is interesting. See: SW, p. 86-91.
} 
difficulties of Fichte's idea of national education can be symbolically seen in his idea that children and youth should be educated in a closed circle of an isolated school community.

\title{
Literature
}

Fichte, J.G. (1845/1846). Sämmtliche Werke, Herausgegeben von I.H.Fichte. Berlin. (SW).

Rohs, P. (1991). J. G. Fichte. Beck. München.

Scholz, H. (1914). Fichte als Erzieher. Kantstudien 19.

Seidel, H. (1997). Johann Gottlieb Fichte zur Einführung. Hamburg.

\section{ПЕСТАЛОЦИ И ФИХТЕ - МОһ ВАСПИТАњА}

\author{
Зоран Димић \\ Универзитет у Нишу, Филозофски факултет
}

\begin{abstract}
Ancmракm: У тексту се истражује однос између Песталоција и Фихтеа. Аутор заступа тезу да је, изузимајући Канта, Песталоци извршио вероватно најснажнији утицај на развој Фихтеове филозофије, те нарочито на његово стављање васпитања у фокус своје филозофије. Утицај Песталоција на Фихтеа је највидљивији управо у Фихтеовој критици постојећег васпитања и изградњи једне сасвим нове концепције васпитне делатности. Управо на овом месту, Фихте се непосредно ослања на Песталоцијеве увиде о важности самосталности и самоделатности у педагошкој пракси. Истовремено, између њих двојице постоје и значајне разлике, јасно видљиве у Фихтеовој концепцији националног васпитања. Ова Фихтеова концепција никако се не сме сагледавати само из контекста Говора немачкој нацији, већ се мора посматрати у целини развоја Фихтеове филозофије, те нарочито у односу на историјске и васпитне прилике које су владале у то време.
\end{abstract}

Кључне речи: васпитање, самосталност, самоделатност, себичност, нација.

\section{Цитирање чланка:}

Dimić, Z. (2021). Pestalozzi and Fichte - the power of education. Godišnjak za pedagogiju 6(2),71-81. 